\title{
Nigerian agriculture workers' outcomes from perceived organisational support and protestant work ethics: Job satisfaction as a mediator
}

\author{
Authors: \\ Olugbenga J. Ladebo ${ }^{1}$ \\ Bello Z. Abubakar ${ }^{2}$ \\ Comfort O. Adamu ${ }^{1}$

\section{Affiliations:} \\ ${ }^{1}$ Department of Agricultural \\ Extension and Rural \\ Development, University \\ of Agriculture, Abeokuta, \\ Nigeria \\ ${ }^{2}$ Department of Agricultura \\ Economics and Extension, \\ Usmanu Danfodiyo \\ University, Sokoto, Nigeria \\ Correspondence to: \\ Olugbenga J. Ladebo \\ Email: \\ lolugbenga@yhoo.com \\ Postal address: \\ PO Box 2316, Sapon, \\ Abeokuta, Ogun State \\ Nigeria \\ Dates: \\ Received: 28 Sept. 2009 \\ Accepted: 08 Mar. 2011 \\ Published: 06 Oct. 2011 \\ How to cite this article: \\ Ladebo, O.J., Abubakar, \\ B.Z., \& Adamu, C.O. (2011). \\ Nigerian agriculture workers \\ outcomes from perceived \\ organisational support and \\ protestant work ethics: Job \\ satisfaction as a mediator. \\ SA Journal of Industrial \\ Psychology/SA Tydskrif vir \\ Bedryfsielkunde, 37(1), Art. \\ \#861, 8 pages. doi:10.4102/ \\ sajip.v37i1.861
}

C 2011. The Authors. Licensee: OpenJournals Publishing. This work is licensed under the Creative Commons Attribution License.
Orientation: The mechanism facilitating the development of organisational commitment and performance of citizenship behaviours is of research interest to scholars. Recent research trends suggest that job satisfaction can mediate the development of employee commitment and citizenship behaviours.

Research purpose: The present study hypothesised that job satisfaction mediated the relationships between the predictors (perceived organisational support and protestant work ethics) and outcomes (organisational citizenship behaviours and organisational commitment).

Motivation for the study: There is paucity of literature on the mediating influence of job satisfaction on predictors-outcomes linkages amongst agriculture workers in Nigeria. Available studies either examined the main effect of perceived organisational support on citizenship behaviours or the mediating influence of satisfaction on citizenship behaviours and not the proposed model.

Research design, approach and method: The present study was survey-correlational in design. Data were obtained from 223 heterogeneous samples from different organisations (such as ministry of agriculture, parastatals, banks, private agro-allied companies, and insurance companies).

Main findings: Results showed that job satisfaction fully mediated the relationship between perceived organisational support and citizenship behaviours and partially mediated the relationship between perceived organisational support and organisational commitment. Further, employee satisfaction partially mediated the relationships between protestant work ethics and citizenship behaviours and organisational commitment.

Practical/managerial implications: This study indicated that both protestant work ethics and perceived organisational support are important in motivating employees to engage in cooperative behaviours and exhibit greater commitment through job satisfaction.

Contribution/value-add: The present study showed that job satisfaction is a mediator linking both perceived organisational support and protestant work ethics to organisational commitment and citizenship behaviours.

\section{Introduction}

Employees' commitment to the organisation and the willingness to perform organisational citizenship behaviours (OCB) has received a good deal of research attention in recent years. Research interest in organisational commitment and OCB is motivated by the desire of organisations to have a highly committed workforce who will perform beyond expectations (i.e. engage in cooperative behaviours that are not in their job description). It is believed that employees perform OCB that acts as a bond holding the organisational community together and improves the well-being of the organisation (LePine, Erez \& Johnson, 2002; Organ, 1988; Vigoda, 2000a). The mechanism facilitating the development of commitment and willingness to perform citizenship behaviour is still receiving research interest. Thus, this paper proposes that job satisfaction has a mediating influence on the development of employee commitment and OCB.

Theoretically, organisational commitment may be viewed in terms of a social exchange relationship in which the employee is expected to identify with, and work towards the realisation of the goals and values of the organisation in return for a range of benefits and rewards (Meyer \& Allen, 1997). 
Employees' commitment develops slowly and consistently over time (Meyer \& Herscovitch, 2001) and is a multidimensional construct comprising of three different types. The affective component, describes an employee's psychological attachment and involvement in the organisation. The second type, continuance commitment relates to the perceived cost associated with leaving the organisation and perceived lack of job alternatives. Normative commitment, the third type, refers to the employee's feelings of obligation to remain with the organisation (Wasti, 2003).

The affective form of commitment is widely studied because it is believed to be a better predictor of employees' behavioural outcomes (Meyer \& Allen, 1997; Wasti, 2003). Highly committed employees experience greater mental and physical well-being, achieve higher in-role performance, perform citizenship behaviours, and would not consider leaving the job thereby ensuring low staff turnover (Meyer \& Herscovitch, 2001; Siu, 2002).

The OCB construct was defined as a general tendency to be cooperative and helpful in organisational work environments (LePine et al., 2002). Employees' acts considered as OCB include helping and cooperating with co-workers in the workplace, and being supportive of organisational goals and objectives. Literature on employment relations indicates that employees engage in cooperative behaviours as a personal obligation to assist co-workers and the organisation (CoyleShapiro, Kessler \& Purcell, 2004; Janssens, Sels \& Van den Brande, 2003). Performance of OCB is facilitated when the organisation provides a supportive, fair, and competitionfree environment for employees. Where there are inequity, unfair treatment, and unfulfilled personal goals by employees in the work environment, employees refuse to perform OCB (Vigoda, 2000b). A lack of willingness to perform OCB may actually predispose employees to engage in withdrawal behaviour, exercise turnover cognitions (Ladebo, 2005; Pare \& Tremblay, 2007), or turnover (Chen, Hui \& Sego, 1998).

Literature suggests that personal and situational variables may explain employee commitment and OCB. The perceived organisational support (POS) (situational) and protestant work ethic (PWE) have been widely reported to be related to commitment and citizenship behaviours (Bishop, Scott, \& Burroughs, 2000; Rhoades \& Eisenberger, 2002; Ryan, 2002). However, the mechanism facilitating the relationships between POS and PWE and both OCB and commitment remains of much research interest to scholars. The present model suggests that job satisfaction could be a mediator linking both POS and PWE to the outcomes.

Studies have implicated employee satisfaction as a mediator responsible for employees' attitudes, behaviour, well-being, and positive organisational outcomes. An employee's satisfaction with a job position mediates the impact of individual and organisational factors on employees' intentions to quit (Addae \& Parboteeah, 2006; Chiang, Back, \& Canter, 2005), organisational commitment (Knights \& Kennedy, 2005; Yousef, 2002), citizenship behaviour (Ladebo,
2008), and organisational performance (Reisel, Chia, Maloles \& Slocum, 2007). However, most of the empirical studies have concentrated on traditional samples from the United States of America and European countries and have seldom targeted highly skilled workers (such as agriculture personnel) from an African country (such as Nigeria) as their unit of analysis. Generally, there is paucity of literature on focal constructs amongst skilled workers in Nigeria.

Available studies either examined the main effect of POS on OCB (Ehigie \& Otukoya, 2005) or the mediating influence of satisfaction on OCB (Ladebo, 2008) and not the proposed model including the focal constructs in the present study. The present study adds to the literature by investigating the mediating influence of job satisfaction on the linkage between both POS and PWE, and commitment and OCB for agriculture workers. Further, using samples from other countries allow us to see whether American management theories, which reflect American culture, are transferable to other countries (Hofstede, 1993).

\section{Protestant work ethics (PWE)}

The PWE (as a personal value) describes an individual's belief that hard work leads to success and that failure is caused by self-indulgence and a lack of self-discipline (Mirels \& Garrett, 1971). Weber (1958) explicated on the PWE as a constellation of beliefs characterised by regard for hard work, self-reliance, frugality, ascetic existence, moderate consumption, and a distaste for unstructured leisure time. Weber ascribed the rise and success of modern capitalism to the possession of PWE by workers. Capitalism became possible because of the view that people have a moral duty to work diligently, regardless of their status in life. PWE is particularly important in work settings and PWE adherents are highly valued. This work value is equally endorsed by both male and female employees (Ali, Falcone \& Azim, 1995).

PWE explains employees' attitudes, work-related activities, and behavioural tendencies. Employees who have internalised work ethic values develop high involvement in their job (Brown, 1996; Cohen, 1999), are satisfied with their job (Gorgievski-Duijvesteijn, Steensma, \& Te Brake, 1998), show strong commitment to the organisation (Williams \& Sandler, 1995), and perform certain citizenship behaviours (Ryan, 2002). Thus, it is hypothesised that endorsement of PWE by employees will facilitate attachment to the organisation and motivates engagement in cooperative behaviours:

- Hypothesis 1: PWE is positively related to organisational commitment (OC) and OCB.

\section{Perceived organisational support (POS)}

Research indicates that employees expect certain inducements in terms of enriched jobs, socio-emotional support, and a hospitable work environment from their employers in exchange for their contributions towards the achievement of organisational goals (Kickul \& Liao-Troth, 2003). In 
exchange for employees' loyalty and higher performance, organisations have shown commitment to employees by providing them with job security, affiliation and emotional support (Eisenberger, Huntington, Hutchison \& Sowa, 1986; Rhoades \& Eisenberger, 2002).

The perceived support from the organisation motivates employees to personify and ascribe human-like characteristics to the organisation and form a generalised belief that the organisation values their contribution and cares about their personal welfare. Discretionary resources such as income, promotions, and job enrichment from the organisation are highly valued by the employees, because they indicate the organisation's commitment to their wellbeing (Eisenberger et al., 1986; Rhoades \& Eisenberger, 2002). Based on Gouldner's (1960) norm of reciprocity, the receipt of valued resources from the organisation will trigger the reciprocation process in which employees are obliged to reciprocate the organisation's beneficial actions directed at them. Employees' psychological contract is strengthened by this continued reciprocation of resources beyond the requirements of formal agreements. In contrast, the perceived withdrawal of beneficial discretionary actions contributes to the view of an unsupportive employer. Perceived breach of contract by the organisation causes employees to reduce their perceived obligations (Aselage \& Eisenberger, 2003; CoyleShapiro, 2002).

Higher levels of POS motivate employees to respond with favourable work attitudes and behaviours. Studies rooted in social exchange indicate that employees who perceived higher commitment and support from the organisation reciprocated with greater attachment to the goals and values of the organisation (Bishop et al., 2000; Ladebo, 2009), performed citizenship behaviours, and reported enhanced psychological well-being (i.e. mood) (Ladebo, 2009; Rhoades \& Eisenberger, 2002). In line with previous studies, this article suggests that $\mathrm{POS}$ is positively related to $\mathrm{OC}$ and $\mathrm{OCB}$ :

- Hypothesis 2: POS is positively related to OC and OCB.

\section{Mediating effect of job satisfaction}

Job satisfaction as an indication of employee well-being refers to the positive affect an employee has towards certain aspects of the job (De Jonge \& Schaufeli, 1997; Noe, Hollenbeck, Gerhart \& Wright, 1994). It is an attitude that develops in response to job or organisational characteristics and enduring individual traits, values, and preferences; it is stable over time and across situations. Higher satisfaction promotes higher self-esteem, as well as physical, and emotional wellbeing (Faragher, Cass \& Cooper, 2005).

Most studies on employees' affective responses have treated job satisfaction as either an antecedent or outcome variable. However, recent research shows that greater satisfaction is a mechanism for the development of employee commitment and involvement in cooperative behaviours (Ladebo, 2008; Yoon \& Thye, 2002) and diminished negative workplace outcomes such as workplace injuries (Barling, Kelloway \&
Iverson, 2003). The mediating influence of job satisfaction could be because of two reasons: firstly, PWE and POS are related to higher satisfaction and secondly, increased satisfaction motivates greater performance of citizenship behaviours and stronger organisational commitment. There is ample empirical evidence supporting that these two conditions influence job satisfaction (Ladebo, 2004, 2008; Randall \& Cote, 1991; Rhoades \& Eisenberger, 2002: Yoon \& Thye, 2002).

From the social exchange standpoint, employees are in interactions with the organisation and are motivated by expected inducements in exchange for their contribution to the organisation. When the organisation fails to reciprocate the contributions of the employees, this may evoke moodiness and frustration in employees (Eisenberger et al., 2001; Luthans, 1998). A frustrated employee may rationalise the imbalance by lowering his or her job satisfaction (Luthans, 1998; Taylor \& Tekleab, 2004). In line with the norm of reciprocity, the perceived supportiveness of an organisation tends to evoke higher satisfaction in employees. Support for the POSsatisfaction relationship can be found in a meta-analysis by Rhoades and Eisenberger (2002), which indicated an average corrected correlation of $r=0.62(p<0.001)$. Further, there is the notion that an employee who values and engages in hard work also derives pleasure from the job. The direct effect of PWE on satisfaction has been established in the literature (Randall \& Cote, 1991).

In support of the proposed mediating mechanism of job satisfaction outlined earlier, empirical evidence indicates that satisfied employees performed citizenship behaviours (Ladebo, 2004, 2008; LePine et al., 2002) and exhibited greater commitment to the organisation (Yoon \& Thye, 2002).

The social exchange framework indicates that job satisfaction is more proximal to both, conditions of employees' attachment to the organisation and their willingness to engage in cooperative behaviour. This paper suggests that the initial effects of POS and PWE will be on job satisfaction and this will mediate subsequent effects on employee commitment and OCB. Thus, the following hypotheses are postulated:

- Hypothesis 3: Job satisfaction will mediate the relationship between PWE and employee outcomes (OC and OCB).

- Hypothesis 4: Job satisfaction will mediate the relationship between POS and employee outcomes (OC and $\mathrm{OCB})$.

\section{Research design \\ Research approach}

This study was a descriptive survey research that employed primary data. Participants were full-time employees that had spent at least two years on the job and employed in agriculture units of different organisations (such as ministry of agriculture, parastatals, private agro-allied companies, banks, and insurance companies). 
Ten full-time employed, postgraduate students at the Federal University of Agriculture in southwest Nigeria were requested to assist with data collection. Each student was given 35 questionnaires to administer to employees in his or her workplace. The respondents returned 223 completed surveys (i.e. 63.71\%). The respondents were fulltime employees with the civil service, an insurance company, banks, government parastatals, and agro-based private companies. The total population in the sampled organisations ranged between 107 and 164. Surveys were administered to staff in the agriculture unit of selected organisations and the useable responses that were received ranged between 19 and 28. The implication of employing a heterogeneous sample in this study is to minimise the influence of contextual constraints of a single organisation (Rousseau \& Fried, 2001). Most of the participants were male $(n=179$, i.e. $80.3 \%)$. The participants' mean age was 40.70 years $(\mathrm{SD}=7.51$ years). They spent between 3 and 38 years on the job, with a mean of 11.74 years' experience ( $\mathrm{SD}=7.09$ years).

\section{Measures}

Affective organisational commitment: This was assessed by a 6-item scale (Meyer \& Allen, 1997). A sample item is: 'I feel a strong sense of belonging to my organisation'. Reliability and validity were good (Ladebo, 2006; Meyer \& Allen, 1997; Meyer \& Herscovitch, 2001; Wasti, 2003).

Organisational citizenship behaviours: The overall OCB was measured by an 8-item measure adapted from the works of Bettercourt, Gwinner and Meuter (2001). An example item is: 'I encourage friends and family to patronise the services and products of my organisation'. The scale's internal consistency and construct validity were good (see Bettercourt et al., 2001).

Job satisfaction: Overall job satisfaction was assessed by a 6-item scale (Brayfield \& Rothe, 1951). This scale was designed to measure satisfaction conceptualised as overall satisfaction rather than as facet satisfaction (e.g. satisfaction with pay, boss and promotion opportunity). Good reliability and validity have been demonstrated (Brayfield \& Rothe, 1951; Ladebo, Olaoye \& Adamu, 2008). An example item is: 'I find real enjoyment in my job'.

Protestant work ethics: The PWE was assessed by a 16item measure adapted from Mirels and Garrett (1971). A sample scale item is: 'Most people spend too much time in unprofitable amusements'. The reliability coefficient for the original scale was 0.79 and past studies have reported similar results (Ryan, 2002).

Perceived organisational support: This was measured with an adapted 7-item measure from Eisenberger et al. (1986). A sample item is: 'My organisation values my contribution to its wellbeing'. The psychometric properties of the scale have been demonstrated by past studies (see Eisenberger et al., 1986; Rhoades \& Eisenberger, 2002).
All the scale items employed in this study were rated on a 5-point frequency of 1 ('strongly disagree') to 5 ('strongly agree'). Where necessary, negative scale items were reverse scored and scale scores were computed by summing across responses to items in a scale.

Demographics: Four biographics (age, sex, tenure and rank) that were likely to co-vary with the mediator and criteria but not of direct interest in this study were controlled for. Age and tenure were measured as continuous variables.

\section{Statistical analysis}

The hierarchical regression procedure was employed to test for hypothesised mediation effect in this study. The hypothesised mediating effect of job satisfaction on the predictors-outcomes linkages was determined using the four-step rule outlined by Preacher and Leonardelli (2001). Firstly, the effect of the predictors (POS and PWE) on the mediator (job satisfaction) was examined. Secondly, the effect of the predictors on each criterion variable (OC and OCB) independent of job satisfaction was investigated. Thirdly, the effect of job satisfaction on each criterion variable was examined. Lastly, evidence of partial or full mediation was determined by including job satisfaction along with POS and PWE as predictors of each criterion variable. Evidence of partial mediation is obtained when the effect of the predictors on the criterion becomes less, as indicated by the change in regression coefficients and the Sobel test (Preacher \& Leonardelli, 2001). There is full mediation when such an effect becomes nonsignificant.

\section{Results}

Table 1 presents means, standard deviations (SD), internal consistency reliabilities, and correlations for each of the measures. The descriptive statistics in Table 1 indicate interesting findings. Only the reported levels of OCB was relatively high $(M=4.35, \mathrm{SD}=0.42)$ whereas the other variables were moderate: $\operatorname{PWE}(M=3.61, \mathrm{SD}=0.46)$, POS $(M=3.32, \mathrm{SD}=0.75)$, job satisfaction $(M=3.51, \mathrm{SD}=0.71)$, and $\mathrm{OC}(M=3.87, \mathrm{SD}=0.78)$. Consistent with past studies, correlations between the variables are positive and generally small to moderate (Table 1).

\section{Test of hypotheses}

It was hypothesised that the predictors (PWE and POS) could be positively related to OC and OCB. The hierarchical regression results in Table 2 indicate significant main effects for PWE and POS in step II after the biographics (age, sex, tenure and rank) were controlled for in step I. PWE was positively related to OCB $(b=0.09, p<0.001)$ and OC $(b=13, p<0.001)$ therefore supporting Hypothesis 1. Similarly, Hypothesis 2 was supported because POS was significantly related to OCB $(b=13, p<0.001)$ and OC $(b=43, p<0.001)$. In step III, there was a positive relationship between job satisfaction and OCB $(b=0.16, p<0.01)$ and OC $(b=0.42, p<0.001)$. 
TABLE 1: Intercorrelation of variables, alpha coefficients and descriptive statistics.

\begin{tabular}{|c|c|c|c|c|c|c|c|c|c|}
\hline Variable & 1 & 2 & 3 & 4 & 5 & 6 & 7 & 8 & 9 \\
\hline 1. Age & - & - & - & - & - & - & - & - & - \\
\hline 2. Sex & $-0.18^{* *}$ & - & - & - & - & - & - & - & - \\
\hline 3. Tenure & $0.69 * *$ & -0.09 & - & - & - & - & - & - & - \\
\hline 4. Rank & $0.50 * *$ & -0.05 & $0.60 * *$ & - & - & - & - & - & - \\
\hline 5. Job satisfaction & $0.21 * *$ & 0.07 & $0.13^{*}$ & 0.05 & 0.79 & - & - & - & - \\
\hline 6. Protestant work ethics & $0.19 * *$ & 0.07 & $0.18^{* *}$ & 0.11 & $0.26^{* *}$ & 0.72 & - & - & - \\
\hline 7. Organisational commitment & $0.24^{* *}$ & -0.05 & $0.23^{* *}$ & $0.16^{*}$ & $0.59 * *$ & $0.31^{* *}$ & 0.88 & - & - \\
\hline 8. POS & $0.20 * *$ & 0.05 & $0.17^{* *}$ & $0.14^{*}$ & $0.56^{* *}$ & $0.17^{* *}$ & $0.54^{* *}$ & 0.86 & - \\
\hline 9. ОСВ & 0.11 & -0.07 & 0.08 & 0.05 & $0.33^{* *}$ & $0.26 * *$ & $0.41^{* *}$ & $0.27^{* *}$ & 0.62 \\
\hline Mean & 40.7 & - & 11.74 & - & 3.51 & 3.61 & 3.87 & 3.32 & 4.35 \\
\hline SD & 7.51 & - & 7.09 & - & 0.71 & 0.46 & 0.78 & 0.75 & 0.42 \\
\hline
\end{tabular}

POS, perceived organisational support; OCB, organisational citizenship behaviours; SD, standard deviation.

Values are given as $N=223$.

Alpha reliability coefficients in bold italic in diagonal.

$*, p<0.05 ; * *, p<0.01$

Furthermore, in Table 2, in step III the hypothesised mediating influence of job satisfaction was examined. The inclusion of job satisfaction in the equation led to a decrease in magnitude of regression coefficient of PWE with OCB $(b=0.07, p<0.01)$ and OC $(b=0.09, p<0.01)$. The Sobel test indicated significant partial mediation influence of job satisfaction on OCB $(Z=3.18, p<0.05)$ and OC $(Z=6.76$, $p<0.05)$. These results support Hypothesis 3 that higher PWE leads to job satisfaction, which in turn, motivates employees' psychological attachment to the organisation and willingness to perform OCB. However, there is a full mediation effect by job satisfaction on the POS $\rightarrow$ OCB linkage ( $b=0.06$, not significant) and partial mediation for POS $\rightarrow$ OC relationship $(b=26, p<0.001)$ (Sobel $Z=10.12, p<0.05$ ) (Table 2). Thus, job satisfaction fully mediates the relation between POS and OCB and partially mediates the POS $\rightarrow$ OC linkage in support of Hypothesis 4.

However, two alternative models to those hypothesised in this study were tested. The first alternative model posited that organisational commitment would mediate the relationships between job satisfaction and PWE and POS. Secondly, OCB would mediate the linkages between job satisfaction and PWE and POS. The results showed that organisational commitment fully mediated the relationship between PWE and job satisfaction whilst it partially mediated the POS $\rightarrow$ job satisfaction linkage $(b=0.28, p<0.0001)$ (Sobel $Z=4.83$, $p<0.05)$. The citizenship behaviours partially mediated the relationships between job satisfaction and PWE $(b=0.07$, $p<0.05)($ Sobel $Z=2.07, p<0.05)$ and POS $(b=0.39, p<0.0001)$ (Sobel $Z=2.22, p<0.05$ ).

\section{Discussion}

The aim of the present study was to test a model linking the predictors (POS and PWE), job satisfaction and employee outcomes (OCB and commitment) amongst agriculture workers in Nigeria. The findings indicate that the predictors (POS and PWE) and job satisfaction are important in explaining OCB and commitment. As hypothesised, job satisfaction fully mediated the relation between POS and OCB and partially mediated the relationship between POS and commitment. In addition, job satisfaction partially mediated the relationships between PWE and OCB and commitment.

The hypothesised positive relationships between PWE and commitment and OCB were supported in this study. Similar to Ryan (2002), and Williams and Sandler (1995) the endorsement of PWE by respondents is significantly related to OCB and commitments. This result affirms that PWE adherents are likely to engage in cooperative behaviour and show stronger attachment to the organisation.

As expected, the hypothesised positive relationships between POS and commitment and OCB were supported in the present study. In corroboration with past studies higher POS was strongly associated with performance of OCB and commitment (Bishop et al., 2000; Ladebo, 2009; Rhoades \& Eisenberger, 2002). This implies that perceived support from the organisation motivates employees to perform OCB and show stronger attachment to the values of the organisation.

In line with past studies, this study demonstrated that satisfaction on the job could be a reciprocation of perceived support from the organisation (Rhoades \& Eisenberger, 2002) and an endorsement of PWE (Randall \& Cote, 1991). This suggests that agriculture employees reciprocate their employers' perceived support by developing positive affect to the job. And employees who expend greater effort on the job are likely to enjoy their job.

\section{Conclusions and recommendations}

This study indicates that both PWE and POS are important in motivating agriculture employees to develop positive work outcomes (citizenship behaviours and commitment) through job satisfaction. The initial reaction of agriculture employees to POS and endorsement of PWE is a satisfaction with the job. Satisfaction with a job provides the motivation for employees to develop attachment to the values and goals of the organisation, and engage in OCB. Therefore, the mediating effect of job satisfaction is important in understanding agriculture employees' outcomes. An implication of this study is that job satisfaction is amenable to managerial 
TABLE 2: Hierarchical regression results for predictors, mediator and outcomes.

\begin{tabular}{|c|c|c|c|c|c|c|c|}
\hline \multirow[t]{2}{*}{ Variable } & \multirow{2}{*}{$\begin{array}{c}\text { Satisfaction } \\
b\end{array}$} & \multicolumn{3}{|c|}{ Citizenship behaviours } & \multicolumn{3}{|c|}{ Commitment } \\
\hline & & $b_{1}$ & $b_{2}$ & $b_{3}$ & $b_{1}$ & $b_{2}$ & $b_{3}$ \\
\hline \multicolumn{8}{|l|}{ Step I: Personals } \\
\hline 1. Age & $0.15^{*}$ & 0.03 & 0.00 & 0.00 & 0.09 & 0.02 & -0.01 \\
\hline 2. Sex & 1.27 & -0.39 & -0.74 & -0.84 & -0.18 & -0.99 & -1.24 \\
\hline 3. Tenure & 0.00 & 0.00 & 0.00 & 0.00 & 0.07 & 0.05 & 0.06 \\
\hline 4. Rank & -0.47 & 0.00 & -0.03 & 0.06 & 0.06 & -0.04 & 0.2 \\
\hline $\mathrm{R}^{2}$ (adjusted) & -0.05 & 0.05 & 0.00 & - & 0.05 & - & - \\
\hline$\Delta \mathrm{R}^{2}$ & $(0.07)^{*}$ & -0.02 & - & - & $(0.07)^{*}$ & - & - \\
\hline \multicolumn{8}{|l|}{ Step II: Main } \\
\hline 5. PWE & $0.08^{*}$ & - & $0.09 * *$ & $0.07^{\mathrm{a}, *}$ & - & $0.13^{* *}$ & $0.09^{b, *}$ \\
\hline 6. POS & $0.42^{* *}$ & - & $0.13^{* *}$ & 0.06 & - & $0.43 * *$ & $0.26^{c, * *}$ \\
\hline $\mathrm{R}^{2}$ (adjusted) & 0.35 & - & 0.11 & - & - & 0.35 & - \\
\hline$\Delta \mathrm{R}^{2}$ & $(0.30)^{* *}$ & - & $(0.12)^{* *}$ & - & - & $(0.30)^{* *}$ & - \\
\hline \multicolumn{8}{|c|}{ Step III: Mediator } \\
\hline $\mathrm{R}^{2}$ (adjusted) & - & - & - & 0.14 & - & - & 0.44 \\
\hline$\Delta \mathrm{R}^{2}$ & - & - & - & $(0.04)^{*}$ & - & - & $(0.09)^{* *}$ \\
\hline
\end{tabular}

Values are given as $N=223$.

a, Sobel test $(z)=3.18, p<0.05$

, Sobel test $(z)=6.76, p<0.05$.

c, Sobel test $(\mathrm{z})=10.12, p<0.05$.

$*, p<0.01 ; * *, p<0.001$

interventions. Firstly, human resources managers may wish to select new employees based on the endorsement of PWE. This appears warranted because agriculture employees who have internalised work ethic values readily ascribe to hard work and enjoy their job. Secondly, managers should enact policies that will satisfy the socio-emotional and affiliative needs of employees. When agriculture employees perceive their employers as being supportive by providing resources that the employees need to cope with workplace conditions, this might encourage them to be satisfied with their jobs.

The present study has a number of limitations. Firstly, there is the need to exercise caution in interpreting the results because of the lower reliability of the OCB scale $(\alpha=0.62)$. The lower reliability could have attenuated the relationships between OCB and other variables (Schmitt, 1996). Secondly, the study was cross-sectional making it difficult to determine causal relationships between the predictors, mediator, and outcomes. In addition, there are alternative explanations for the ordering of the variables in this study. There is the possibility that agriculture employees who have high levels of PWE and perceive the organisation as caring may exhibit stronger attachment to the organisation and perform citizenship behaviours, which may produce higher satisfaction. The alternative model was tested and the results are twofold.

Firstly, organisational commitment fully mediated the relationship between PWE and job satisfaction whilst it partially mediated the POS $\rightarrow$ job satisfaction linkage. Thus, in line with extant literature, employees who endorse the protestant work values would develop stronger attachment to the values and goals of the organisation (Williams \& Sandler, 1995), which will result in higher job satisfaction. Further, the partial mediating mechanism of organisational commitment on the linkage between POS and satisfaction, points to the social exchanges between the organisation and its employees. It is believed that employees initially react to the benevolent acts of the organisation by developing a strong sense of belonging to the organisation (Eisenberger et al., 2001; Ladebo, 2009; Rhoades \& Eisenberger, 2002), which will lead to higher job satisfaction.

Secondly, citizenship behaviours partially mediated the relationships between job satisfaction and PWE and POS. In line with past studies, this result suggests that employees would perform OCB because of a strong sense of work ethics as well as in reciprocation for being supported by the employing organisation (Ladebo, 2009; Rhoades \& Eisenberger, 2002; Ryan, 2002). Finally, employees who readily engage in OCB will develop feelings of satisfaction with the job (see Ladebo, 2008). Recent research effort indicates that when employees voluntarily engage in $\mathrm{OCB}$, this results in higher satisfaction as opposed to if organisations compulsorily request the performance of OCB and employees develop dissatisfaction with their job. The performance of some OCBs may arise from abusive supervision, co-ercive managerial strategies, or social pressure by peers (Vigoda-Gadot, 2007). Therefore, employees' commitment to the organisation and willingness to perform citizenship behaviours could each be an outcome for employees or they could mediate outcomes for agriculture workers. These employee attitudes are open to managerial interventions. Therefore, agriculture managers need to understand the factors that promote the employee attitudes to achieve effective management of extension personnel.

However, the results of the alternative model demonstrate the many possible different orderings of focal constructs in this study. Future studies based on longitudinal or experimental designs are required to test the causal relationships amongst 
the variables in this study. Third, this study is based on self-report data obtained at a single time point therefore; there is the possibility of contamination of data because of a monomethod bias.

To eliminate the possibility of method bias, the scale items were ordered randomly in the survey and the data was subjected to Harman's 1-factor test (Podsakoff, MacKenzie, Lee \& Podsakoff, 2003; Podsakoff \& Organ, 1986). The results from a factor analysis of all items suggest that a singledominant factor did not emerge, suggesting that method bias was not responsible for the magnitude of bivariate correlations between the variables. However, scholars suggest that self-reporting is still a vital tool for data collection in organisational behaviour research and that its use may not necessarily lead to inflation of relationships between variables (Bruk-Lee \& Spector, 2006; Harrison, McLaughlin \& Coalter, 1996).

\section{References}

Addae, H.M., \& Parboteeah, K.P. (2006). Organizational information, organizational commitment and intention to quit: A study of Trinidad and Tobago. International Journal of Cross-Cultural Management, 6(3), 343-359. doi:10.1177/1470595806070642

Ali, A.J., Falcone, T., \& Azim, A.A. (1995). Work ethic in the USA and Canada. Journa of Management Development, 14(6), 26-34. doi:10.1108/02621719510086156

Aselage, J., \& Eisenberger, R. (2003). Perceived organizational support and psychological contracts: A theoretical integration. Journal of Organizational psychological contracts: A theoretical integ
Behavior, 24, 491-509. doi:10.1002/job.211

Barling, J., Kelloway, E.K., \& Iverson, R.D. (2003). High-quality work, job satisfaction, and occupation injuries. Journal of Applied Psychology, 88(2), 276-283. doi:10.1037/00219010.88.2.276, PMid:12731711

Bettercourt, L.A., Gwinner, K.P., \& Meuter, M.L. (2001). A comparison of attitude personality and knowledge predictors of service-oriented organizational citizenship behaviors, Journal of Applied Psychology, 86(1), 29-41. doi:10.1037/0021-9010.86.1.29, PMid:11302230

Bishop, J.W., Scott, K.D., \& Burroughs, S.M. (2000). Support, commitment, and employee outcomes in a team environment. Journal of Management, 26(6), 1113-1132. doi:10.1177/014920630002600603

Brayfield, A.H., \& Rothe, H.F. (1951). An index of job satisfaction. Journal of Applied Psychology, 35, 307-311. doi:10.1037/h0055617

Brown, S.P. (1996). A meta-analysis and review of organisational research on job involvement. Psychological Bulletin, 120(2), 235-255. doi:10.1037/00332909.120.2.235

Bruk-Lee, V., \& Spector, P.E. (2006). The social stressors-counterproductive work behaviors link: Are conflicts with supervisors and coworkers the same? Journal of Occupational Health, 11(2), 145-156. doi:10.1037/1076-8998.11.2.145, PMid:16649848

Chen, X.-P., Hui, C., \& Sego, D.J. (1998). The role of organizational citizenship behaviou in turnover: Conceptualization and preliminary tests of key hypotheses. Journal of in turnover: Conceptualization and preliminary tests of key hypotheses.

Chiang, C.-F., Back, K.-J., \& Canter, D.D. (2005). The impact of employee training on job satisfaction and intention to stay in the hotel industry. Journal of Human
Resources in Hospitality \& Tourism, 4(2), 99-118. doi:10.1300/J171v04n02_06, PMCid:2510168

Cohen, A. (1999). Relationships among five forms of commitment: An empirical assessment. Journal of Organizational Behavior, 20, 285-308. doi:10.1002/ (SICI)1099-1379(199905)20:3<285::AID-JOB887>3.0.CO;2-R

Cohen, A., \& Keren, D. (2008). Individual values and social exchange variables: Examining their relationships to and mutual effects on in-role performance and organizational citizenship behaviour. Group \& Organization Management, 33(4) 425-452. doi:10.1177/1059601108321823

Coyle-Shapiro, J.A.M., Kessler, I., \& Purcell, J. (2004). Exploring organizationally directed citizenship behaviour: Reciprocity or 'it's my job'? Journal of Managemen Studies, 41(1), 85-106. doi:10.1111/j.1467-6486.2004.00422.x

Coyle-Shapiro, J.A.M. (2002). A psychological contract perspective on organisational citizenship behavior. Journal of Organizational Behavior, 23, 927-946. doi:10.1002/job.173

De Jonge, J., \& Schaufeli, W.B. (1997). Job characteristics and employee well-being: A test of Warr's Vitamin Model in health care workers using structural equation modelling. Journal of Organizational Behavior, 18, 320-341.

Eisenberger, R., Huntington, R., Hutchison, S., \& Sowa, D. (1986). Perceived organizational support. Journal of Applied Psychology, 71(3), 500-507. doi:10.1037/0021-9010.71.3.500
Eisenberger, R., Cummings, J., Armeli, S., \& Lynch, P. (1997). Perceived organizational support, discretionary treatment, and job satisfaction. Journal of Applied support, discretionary treatment, and job satisfaction. Journal of Appli
Psychology, 82, 812-820. doi:10.1037/0021-9010.82.5.812, PMid:9337610

Eisenberger, R., Armeli, S., Rexwinkel, B., Lynch, P.D., \& Rhoades, L. (2001). Reciprocation of perceived organizational support. Journal of Applied Psychology, 86(1), 42-51. doi:10.1037/0021-9010.86.1.42, PMid:11302232

Faragher, E.B., Cass, M., \& Cooper, C.L. (2005). The relationship between satisfaction and health: a meta analysis. Occupation and Environmental Health Medicine, 62 105-112.

Gorgievski-Duijvesteijn, M., Steensma, H., \& Te Brake, E. (1998). Protestant work ethics as a moderator of mental and physical well-being. Psychological Reports, 83, 1043-1050. doi:10.2466/PR0.83.7.1043-1050, PMid:9923184

Gouldner, A.W. (1960). The norm of reciprocity: A preliminary statement. American Sociological Review, 25, 161-179. doi:10.2307/2092623

Harrison, D.A., McLaughlin, M.E., \& Coalter, T.M. (1996). Context, cognition, and common method variance: Psychometric and verbal protocol evidence. Organizational Behavior and Human Decision Processes, 68(3), 246-261. doi:10.1006/obhd.1996.0103

Hofstede, G. (1993). Cultural constraints in management theories. Academy of Management Executive, 7, 81-94.

Janssens, M., Sels, L., \& Van den Brande, I. (2003). Multiple types of psychological contracts: A six-cluster solution. Human Relations, 56(11), 1349-1378. doi:10.1177/00187267035611004

Kickul, L., \& Liao-Troth, M.A. (2003). The meaning behind the message: Climate perceptions and the psychological contract. Mid-American Journal of Business, 18(2), 23-32.

Knights, J.A., \& Kennedy, B.J. (2005). Psychological contract violation: Impacts on job satisfaction and organizational commitment among Australian senior public servants. Applied Human Resources Management Research, 10(2), 57-72.

Ladebo, O.J. (2004). Employees' personal motives for engaging in citizenship behaviors: The case of workers in Nigeria's agriculture industry. Current Research in Social Psychology, 9(16), 220-233.

Ladebo, O.J. (2005). Relationship between citizenship behaviors and tendencies to withdraw among Nigerian agribusiness employees. Swiss Journal of Psychology, 64(1), 41-50. doi:10.1024/1421-0185.64.1.41

Ladebo, O.J. (2006). Perceptions of trust and employees' attitudes: A look at Nigeria's agricultural extension workers. Journal of Business and Psychology, 20(3), 409427. doi:10.1007/s10869-005-9014-1

Ladebo, O.J. (2008). Perceived supervisory support and organizational citizenship behaviors: Is job satisfaction a mediator? South African Journal of Psychology, 38(3), 479-488.

Ladebo, O.J., Olaoye, O.J., \& Adamu, C.O. (2008). Extension personnel's self-esteem and workplace relationships: Implications for job satisfaction and affective 14(3), 249-263. doi:10.1080/13892240802207692

Ladeo, O.J. (2009). Emotional exhaustion and strain reactions: Perceived organisational support a moderator. South African Journal of Psychology, 39(1), 46-58.

LePine, J.A., Erez, A., \& Johnson, D.E. (2002). The nature and dimensionality of organizational citizenship behavior: A critical review and meta-analysis. Journal of Applied Psychology, 87(1), 52-65. doi:10.1037/0021-9010.87.1.52, PMid:11916216

Luthans, F. (1998). Organizational behavior. (8th edn.). Boston, MA: Irwin Mc-GrawHill Publishers.

Meyer, J.P., \& Allen, N.J. (1997). Commitment in the workplace: Theory, research and application. Thousand Oaks, CA: Sage Pub.

Meyer, A., \& Herscovitch, L. (2001). Commitment in the workplace: Toward a general model. Human Resource Management Review, 11, 299-326. doi:10.1016/S10534822(00)00053-X

Mirels, H.L., \& Garrett, J.B. (1971). The protestant ethic as a personality variable. Journal of Consulting and Clinical Psychology, 36, 40-44. doi:10.1037/h0030477, PMid:5542480

Noe, R.A., Hollenbeck, J.R., Gerhart, B., \& Wright, P.M. (1994). Human resource management: Gaining a competitive advantage. Burrridge, IL: Irwin Inc.

Organ, D.W. (1988). Organizational citizenship behaviour: The good soldier syndrome. Lexington, MA: Lexington Books.

Pare, G., \& Tremblay, M. (2007). The influence of high-involvement human resources practices, procedural justice, organizational commitment, and citizenship behaviors on information technology professionals' turnover intentions. Group \& Organization Management, 32(3), 326-357. doi:10.1177/1059601106286875

Podsakoff, P.M., \& Organ, D.W. (1986). Self-reports in organizational research: Problems and prospects. Journal of Management, 12, 521-544. doi:10.1177/014920638601200408

Podsakoff, P.M., MacKenzie, S.B., Lee, J.-Y, \& Podsakoff, N.P. (2003). Common method biases in behavioral research: A critical review of the literature and recommended remedies. Journal of Applied Psychology, 88(5), 879-903. doi:10.1037/00219010.88.5.879, PMid:14516251

Preacher, K.J., \& Leonardelli, G.J. (2001). Calculation for the Sobel test: An interactive calculation tool for mediation tests (Computer software). Retrieved June 27 2005, from http://www.unc.edu/ preacher/sobel/sobel.htm

Randall, D.M., \& Cote, J.A. (1991). Interrelationships of work commitment constructs. Work and Occupation, 18, 194-211. doi:10.1177/0730888491018002004

Reisel, W.D., Chia, S.-L., Maloles, C.M., \& Slocum, J.W. (2007). The effects of job insecurity on satisfaction and perceived organizational performance. Journal of Leadership \& Organizational Studies, 14(2), 106-116. doi:10.1177/1071791907308055 
Rhoades, L., \& Eisenberger, R. (2002). Perceived organizational support: A review of the literature. Journal of Applied Psychology, 87(4), 698-714. doi:10.1037/00219010.87.4.698, PMid:12184574

Rousseau, D.M., \& Fried, Y. (2001). Location, location, location: Contextualizing organizational research. Journal of Organizational Behavior, 22, 1-13. doi:10.1002/job.78

Ryan, J.J. (2002). Work values and organizational citizenship behaviours: Values that work for employees and organizations. Journal of Business and Psychology, 17(1) 123-132. doi:10.1023/A:1016246103190

Schmitt, N. (1996). Uses and abuses of coefficient alpha. Psychological Assessment, 8, 350-353. doi:10.1037/1040-3590.8.4.350

Siu, O.-L. (2002). Occupational stressors and well-being among Chinese employees: The role of organizational commitment. Applied Psychology: An International Review, 51(4), 527-544. doi:10.1111/1464-0597.t01-1-00106

Taylor, M.S., \& Tekleab, A.G. (2004). Taking stock of psychological contract research Assessing progress, addressing troublesome issues, and setting research priorities. In J.A.M. Coyle-Shapiro, L.M. Shore, M.S. Taylor \& L.E. Tetrick (Eds.), The Employment relationship. Examining psychological and contextual perspectives (pp. 253-283). Oxford, UK: Oxford University Press.

Vigoda, E. (2000a). Internal politics in public administration systems: An empirical examination of its relationship with job congruence, organizational citizenship behavior, and in-role performance. Public Personnel Management, 29(2), 185210
Vigoda, E. (2000b). Organizational politics, job attitudes, and work outcomes: Exploration and implications for the public sector. Journal of Vocational Behavior 57, 326-347. doi:10.1006/jvbe.1999.1742

Vigoda-Gadot, E. (2007). Redrawing the boundaries of OCB? An empirical examination of compulsory extra-role behavior in the workplace. Journal of Business and Psychology, 21(3), 377-405. doi:10.1007/s10869-006-9034-5

Wasti, S.A. (2003). The influence of cultural values on antecedents of organizational commitment: An individual-level analysis. Applied Psychology: An International Review, 52(4), 533-554. doi:10.1111/1464-0597.00150

Weber, M. (1958). The Protestant ethic and the spirit of capitalism. (T. Parsons, Trans.) New York: Scribner. (Originally published 1904-1905).

Williams, S., \& Sandler, R.L. (1995). Work values and attitudes: protestant and Confucian ethics as predictors of satisfaction and commitment. Research and Practice in Human Resource Management, 3(1), 1-13.

Yoon, J., \& Thye, S.R. (2002). A dual process model of organizational commitment: Job satisfaction and organizational support. Work and Occupations, 29(1), 97-124. doi:10.1177/0730888402029001005

Yousef, D.A. (2002). Job satisfaction as a mediator of the relationship between job stressors and affective, continuance, and normative commitment: A path analytical approach. International Journal of Stress Management, 9(2), 99-112. doi:10.1023/A:1014954703735 